\title{
Ammatilliset kurssikeskukset muutosten edessä
}

Viime talven lumilla kurssikeskuksessamme oli tiedotustilaisuus, jonne oli kutsuttu läänin tiedotusvälineiden edustajat. Varsinaisen tilaisuuden jo loputtua erään radion toimittaja kysäisi, eikö olekin mukavaa, kun nykyään kaikki ovat kiinnostuneita teidän toiminnastanne. Mitä siihen muuta kuin myöntämään. Mutta kuinka tähän sitten on tultu?

Kurssikeskusten käynnistysvaihe ajoittui tilanteeseen, jolloin Suomessa tapahtui voimakas elinkeinorakenteen muutos. Tällöin koulutettiin ne suuret maassamuuttaneiden joukot, jotka useimmiten siirtyivät työskentelemään itselleen vieraaseen ympäristöön. Koulutus oli pääasiassa ammatillista peruskoulutusta. Se suuntautui etupäässä teollisuuteen, jossa tarvittiin määrällisesti eniten uutta työvoimaa.

Tuolloin, 1970-luvun alussa, maahan syntyi verkosto, joka nykyään käsittää 42 kurssikeskusta. Vuosittain koulutetaan työllisyyskoulutuksena 15000 oppilaspaikalla runsaat 25000 opiskelijaa. Tämän lisäksi henkilöstökoulutuksena järjestetään erikseen räätälöityjä kursseja, joilla vuosittain opiskelee suuri joukko aikuisia. Esimerkiksi Vaasan ammatillisessa kurssikeskuksessa on kolmena viimeisenä vuonna henkilöstökoulutuskursseilla ollut vuosittain runsaat 900 opiskelijaa, kun työllisyyskoulutuksessa vastaava määrä on ollut noin 300 opiskelijaa.

Ammatillisen aikuiskoulutuksen tarve on muuttunut sitten perustamisaikojen. Kurssikeskukset ovat kehittyneet silloisista pikakouluttajista korkeat laatuvaatimukset täyttäviksi lisä- ja uudelleenkoulutuslaitoksiksi. Koulutus on laajentunut käsittämään teollisuusammattien lisäksi muutkin ammatit. Erittäin voimakasta ekspansio niin laadullisesti kuin määrällisestikin on ollut sekä tietotekniikan eri sovellusohjelmien opettamisessa että palvelualojen ammatteihin kouluttamisessa. Kurssikeskusten lyhyessä historiassa voidaan erottaa toisaalta perustamisponnistelujen vaihe, ja toisaalta uuteen voimakkaasti orientoituva sekä vanhasta tarpeettomaksi käyneestä luopumaan valmis vaihe.

\section{Rakennemuutos ja kurssikeskukset}

Tätä uudelleen suuntautumisvaihetta kuvaavat lähinnä vuoden 1986 laki- ja asetusmuutokset. Se pohjautuu elinkeinojen sisällä tapahtuvaan rakennemuutokseen. Rakennemuutokselle on tyypillistä laadulliset painotukset, nopeus ja totaalisuus - eikä se kunnioita valtakunnan rajoja. On myös ennustettavissa, ettei se ole vaikutuksiltaan kertaluonteinen vaan toistuva, ts. tapahtunut laadullinen muutos on alku seuraavantasoiseen kehitysmuutokseen.

Ammatillisen aikuiskoulutuksen kannalta olennaista yhteiskunnassa tapahtuvissa muutoksissa on, että

- elinkeinojen välinen rakenne muuttuu edelleen

- ammattitaitovaatimusten muutokset kohdistuvat aiempaa voimakkaammin jo ammatissa toimivaan väestöön

- väestön ikärakenne epätasaistuu: työmarkkinoille tulee entistä pienempiä ikäluokkia

- tarvittava uusi työvoima on hankittava työelämässä jo olevia uudelleenkouluttamalla

- työvoiman alueellinen liikkuvuus tulee vähenemään keski-iän lisääntymisen seurauksena

- vanhempien ikäluokkien tullessa lisääntyvässä määrin ammatillisen aikuiskoulutuksen piiriin heidän motivoimisekseen edellytetään aiempaa voimakkaampaa panostusta opiskeluaikaisen toimeentulon järjestämiseen sekä aikuisille soveltuviin opiskelujärjestelyihin

- aikuiskoulutukselta vaaditaan entistä enemmän joustavuutta ja mukautumista ympäröivän työelämän ja kansalaisten todellisiin tarpeisiin

- ammatillisessa aikuiskoulutuksessa koulutuksen kysynnän on päästävä vaikuttamaan koulutustarjonnan muotoutumiseen nykyisten hallinto- ja suunnittelupäätösten sijaan.

Edellä mainittujen muutosten johdosta arvioidaan koulutustarpeen lisääntyvän voimakkaasti. Erään arvion mukaan nykyinen henkilöstökoulutusta kuvaava luku 2,4 koulutuspäi- 
vää työntekijä kohden vuodessa tulee nousemaan vuosituhannen loppuun mennessä 5,7 koulutuspäivään ilman, että otettaisiin huomioon yritysten sisällä tapahtuvaa henkilöstökoulutusta. Resurssien lisäyksen odotetaan tapahtuvan pääasiassa valtion tulo- ja menoarvion ulkopuolisista rahoituslähteistä. Kysyntämalli edellyttää totaalista hallinnollis-taloudellista muutosta ei vain kurssikeskuksissa, vaan koko ammatillista aikuiskoulutusta toteutettavassa kentässä. Omaehtoinen, tutkintotavoitteinen aikuisopiskelu edellyttää myös keskusvirastolta paljon työtä. Lisäresursseja tarvitaan koulutukseen osallistuvien toimeentulon järjestämiseen.

Näihin asioihin on ns. Melametsän toimikunta joutunut ottamaan kantaa mietinnössään. Mietintöä ei tätä kirjoittaessani ole vielä julkaistu, mutta siihen liittyvää keskustelua on valmisteluvaiheessa käyty vilkkaasti monilla tahoilla. Tämä on tietysti hyvä, koska samalla asiaa lähestytään monella tavalla erilaisista intressinäkökohdista. Aika ajoin näyttää kuitenkin unohtuvan, että tämä sinänsä tärkeä valmisteluvaihe luo lähinnä taloudellis-hallinnollisia puitteita. vasta tämän vaiheen jälkeen tulee suuri ja merkittävä joukko toiminnallisen tason asioita ratkaistaviksi, muutettaviksi ja kehitettäviksi.

\section{Mahdollisuuksia vai vaikeuksia?}

Suhtaudun ammatillisen aikuiskoulutuksen tulevaisuuteen mahdollisuuksia tarjoavana, en vaikeuksia tai uhkaa tuovana. Siitä huolimatta on syytä tehdä joukko varmistavia kysymyksiä ennenkuin kannattaa suin päin rynnätä kohti kalaisampia vesiä.

Koulutusken volyymin odotetaan kasvavan ja sitä silmälläpitäen yhä useammat oppilaitokset saavat aikuiskoulutusosastot. Kyetääntö aikuiskoulutuskeskukset ${ }^{1}$ asettamaan samalle lähtöviivalle muiden oppilaitosten kanssa vai joudummeko lähtemään liikkeelle hinnoiltamme kalliimpina? Kysymys on periaatteellinen, mutta myös käytännöllinen. Esimerkiksi edustamani laitos järjestää kolmen päivän tietotekniikkakursseja á $1500 \mathrm{mk} /$ oppilas. Muut oppilaitokset tarjoavat vastaavaa kurssia á 80-350 $\mathrm{mk} /$ oppilas. Todellinen hintakilpailu koulutuksessa tulee kysymykseen vasta silloin, kun tuotteet ovat vertailukelpoiset, se tulisi tuottajien muistaa. Asiakas joutuu kokemaan melkoisia hämmennyksen hetkiä nykyisessä hintaviidakossa.

1 Kurssikeskusten nimi on muuttumassa aikuiskoulutuskeskukseksi.
Aiheuttaako tietoisesti luotu kilpailutilanne tulevaisuudessakin sen, että koulutuksen tarjoajat kilpailevat keskenään laadun kustannuksella. Ratkaisevaa tulee olemaan keskeisen suurasiakkaan so. työvoimaviranomaisen kulutuskäyttäytyminen.

Koulutusmarkkinat ovat myös erilaiset erikokoisilla talousalueilla. Nähtäväksi jää, kykenevätkö eri oppilaitokset järkevään yhteistyöhön silmittömän kilpailun sijaan. Pienemmilläkin talousalueilla kansalaiset ja elinkeinoelämä tarvitsevat laadukasta koulutusta. Sitä tarjoamaan riittää yksi alueellinen oppilaitos. Jokaisen resurssit eivät riitä kaikkeen mahdolliseen koulutukseen.

Kysyntämallin tarkoitus lienee ensisijaisesti taata taloudellinen tehokkuus, joustava tarjonta sekä kohoava laatutaso. Kysyntämallin ei tarvitse tuoda mukanaan vapaan markkinatalouden haitallisimpia piirteitä.

Uusi, kasvava ja monimuotoistuva ammatillinen aikuiskoulutus luo uusia haasteita aikuispedagogiikalle ja -didaktiikalle. Haasteita tulee niin nopeasti, että voidaan kysyä, kykeneekö korkeakoululaitos vastaamaan aikuiskoulutuskeskusten henkilöstön jatko- ja täydennyskoulutustarpeeseen. Riittävätkö resurssit tutkimus- ja kehitystoimintaan? Onko jo käytössä olevat resurssit suunnattu tarkoituksenmukaisesti? Monimuoto-opiskelun edellyttämät laite-investoinnit sekä muut järjestelyt aiheuttavat aikuiskoulutuskeskuksissa sekä muissa oppilaitoksissa melkoista priorisointia.

Aikuiskoulutuksessa työehtosopimuksesta on tullut jarruttava tekijä yhä suurempaa mukautumista ja joustavuutta edellyttävissä tilanteissa. Sopimus on oman historiansa tuote, mutta kyetäänkö se uudistamaan riittävän nopeasti siten, ettei se enää toimisi kehityksen esteenä. Samaan hengenvetoon on sopijaosapuolille peräänkuulutettava, että aikuiskoulutuskeskuksissa tarvitaan muutakin kuin opetushenkilöstöä: koulutussuunnittelijoita, opinto-ohjaajia sekä konsultti-, markkinointi- ja myyntityöstä vastaavia. Heidätkin tulee ottaa huomioon sopimuksissa.

Kasvavat markkinat vetävät tarjoajia puoleensa. Näin kävi turkistarhauksessakin. Sitä tuki valtiokin sillä seurauksella, että tuotteiden laatu laski. Maailmanmarkkinoilla syntyi muille tilaa toimia. Nyt tulisi ammatillisen aikuiskoulutuksen markkinoilla olla riittävästi innovointikykyä, mutta samalla kylmään harkintaan perustuvaa halua yhteistoimintaan. Oppilaitosten on keskityttävä, niiden on voitava keskittyäö omien profiiliensa terävöittämiseen. Tämä edellyttää toimintojen koordinointia oppilaitosten välillä ja jopa alihankintasuhteiden luomista. Kysymys tämän asian kohdalla kuuluu: "Halutaanko yhteistoimintaa ja koordinointia?" 
Kokonaan uudessa tilanteessa toimivien aikuiskoulutuskeskusten tulee saada omaan nahanluontiinsa riittävä kehitystuki. Se pitäisi käyttää sisäiseen koulutukseen, kehitykseen ja työskentelyn uudelleen organisointiin. Ilman voimakasta kehityspanosta sanat jäävät leijumaan tekojen yläpuolelle.
Viime aikoina päässäni on myös pyörinyt epäilys ja huoli tulevan ammatillisen aikuiskoulutusjärjestelmän demokraattisuudesta. Tiedän, että se huolehtii avainalojen ja -työntekijäryhmien koulutusmahdollisuuksista paremmin kuin entinen järjestelmä, mutta miten on niiden avaimettomien laita. 